Luigi Tritapepe MD, Paolo Voci MD,*

Giovanni Pinto MD, Stefano Brauneis MD, Antonio Menichetti MD

\title{
Anaesthesia for Caesarean section in a Marfan patient with recurrent aortic dissection
}

Purpose: We report the anaesthetic management of a 34-yrold pregnant woman with recurrent aortic disection and Marfan syndrome for Caesarean section.

Clinical features: She presented at $28 w k$ gestation with recurrent aortic dissection and had undergone aortic valve replacement and coronary ostia reimplantation (Bentall procedure) in the first trimester of pregnancy. She was treated in hospital with labetalol, anticoagulants and steroids and daily echocardiographic examination until 34 wk when caesarean section was planned. After positioning radial artery and CVP catheters and a transoesophageal echocardiographic probe, general anaesthesia was induced with thiopentone and maintained with isoflurane, and endotracheal intubation was facilitated with vecuronium. The site of incision was infiltrated with lidocaine before surgery which was uneventful. The patient was discharged at 10 days.

Conclusions: With appropriate preoperative care and monitoring, uneventful general anaesthesia for caesarean section was achieved in a patient with Marfan syndrome in the presence of recurrent aortic dissection.

Objectif: Exposer la gestion anesthésique de la césarienne d'une femme de 34 ans enceinte souffrant d'une dissection récidivante de l'aorte avec syndrome de Marfan.

\section{Key words}

ANAESTHESIA: cardiac, obstetric;

COMPLICATIONS: cardiac, Marfan syndrome, aortic dissection.

From the Department of Anaesthesia and Intensive Care and *Department of Cardiovascular Surgery, "La Sapienza" University of Rome-Italy.

Address correspondence to: Dr. Luigi Tritapepe, Istituto di Anestesiologia e Rianimazione, Universita' "La Sapienza", Policlinico Umberto I, Viale del Policlinico, 15500161 Rome, Italy.

Phone: $3964463101 / 4463102$. Fax: 3964461967.

Accepted for publication June 27, 1996.
Éléments cliniques: La patiente qui avait déjà subi une remplacement valvulaire aortique et une réimplantation des orifices coronariens (intervention de Bentall) pendant le premier trimestre de sa grossesse, s'est présentée à sa $28^{e}$ semaine de grossesse avec une dissection récidivante de l'aorte. Elle a été admise à l'hôpital pour un traitement au labétalol, aux anticoagulants et aux stéroïdes, ainsi que pour une échographie cardiaque quotidienne. Une césarienne était programmée pour la $36^{e}$ semaine. Après l'insertion d'une canule radiale, d'une TVC et d'un capteur transoesophagien, l'anesthésie générale était induite avec du thiopentone et maintenue avec de l'isoflurane alors que l'intubation était effectuée à l'aide de vécuronium. Le site de l'incision était infiltré à la lidocaïne avant une chirurgie qui s'est déroulée sans incidents. La patiente était libérée dix jours après l'intervention.

Conclusion: Après une préparation et un monitorage appropriés, une anesthésie générale a été réalisée sans incidents chez une patiente souffrant d'un syndrome de Marfan avec une dissection récidivante de l'aorte.

Marfan's syndrome is an autosomal dominant disorder of connective tissue, characterized by several abnormalities involving the skeletal, ocular and cardiovascular systems. There is a particularly high risk of aortic dissection during pregnancy. ${ }^{1,2}$

We report the management for caesarean section of a patient with recurrent aortic dissection who had undergone replacement of the aortic valve and coronary ostia reimplantation during the first trimester of pregnancy. The goals of anaesthetic management were: (1) to reduce the hyperdynamic cardiovascular responses to intubation and surgery; (2) to avoid high dose narcotic cardiac anaesthesia so that the prolonged depressant effect to the mother and neonate were minimized.

\section{Case report}

A 34-yr-old woman with Marfan syndrome had experienced ascending aorta dissection during the first 
trimester of pregnancy, which required aortic valve conduit replacement and both coronary ostia reimplantation (Bentall operation). Surgery and anaesthesia were carried out without maternal and/or foetal complications. The patient was discharged from hospital receiving only anticoagulant therapy (calciparin 21,000 U $\cdot$ day $^{-1}$ ). At 28 wk gestation, she presented with new, acute chest pain. Arterial pressure was $150 / 90 \mathrm{mmHg}$ and heart rate 90 bpm. Transoesophageal echocardiography showed a new dissection distal to the aortic conduit, involving the arch and thoracic aorta. The patient was hospitalized and treated with an antihypertensive (labetalol $200 \mathrm{mg}$ po o.d.), anticoagulant (calciparin $21,000 \mathrm{U} \cdot$ day $^{-1}$ ) and steroids (betametasone $12 \mathrm{mg}$ bid for three days, before the caesarean section to improve foetal maturation).

Transthoracic echocardiography was performed daily and, at 34 wk gestation, elective Caesarean section in a cardiac surgery theatre was scheduled. A $14 \mathrm{G}$ peripheral iv cannula was inserted for rapid administration of fluids. The patient received $200 \mathrm{mg}$ cimetidine $i v$. After local infiltration of $0.5 \mathrm{ml}$ lidocaine $1 \%$, a $20 \mathrm{G}$ catheter was introduced in the right radial artery for continuous arterial pressure monitoring and a double-lumen central venous catheter was positioned in the right jugular vein to monitor central venous pressure (CVP) and to facilitate infusion cardioactive drugs. The patient was placed in the semi-lateral position to produce left uterine displacement. Blood pressure (BP), heart rate (HR) and CVP were stable $(120 / 70 \mathrm{mmHg}, 75 \mathrm{bpm}, 5 \mathrm{mmHg}$ respectively) and fetal $\mathrm{HR}$ (FHR) was $150 \mathrm{bpm}$. Propranolol (1 mg) and lidocaine $\left(1 \mathrm{mg} \cdot \mathrm{kg}^{-1}\right)$ were administered to limit the anticipated increase in $\mathrm{HR}$ and BP secondary to tracheal intubation and surgical incision. The line of surgical incision was infiltrated with $100 \mathrm{mg}$ lidocaine $0.25 \%$ to attenuate intra- and postoperative pain and to reduce the hyperdynamic response to surgical manoeuvres. Induction of anaesthesia was with thiopentone $\left(4 \mathrm{mg} \cdot \mathrm{kg}^{-1}\right)$ and vecuronium $\left(0.1 \mathrm{mg} \cdot \mathrm{kg}^{-1}\right)$ was used to facilitate tracheal intubation. A single plane transoesophageal probe was introduced for continuous echocardiographic monitoring. Anaesthesia was maintained with isoflurane $(0.5 \%)$ in $100 \%$ oxygen and, using manual ventilation, to maintain $\mathrm{PaCO}_{2}$ between 33-35 mmHg. Oximetry and end-tidal $\mathrm{CO}_{2}$ were monitored. Labetalol was infused $\left(1 \mu \mathrm{g} \cdot \mathrm{kg}^{-1} \cdot \mathrm{min}^{-1}\right)$ to maintain BP constant. The BP, HR, FHR and CVP did not change throughout induction and intubation time (Table).

Three minutes after surgical incision, a $2.4 \mathrm{~kg}$ male infant was delivered; the Apgar scores at one and five minutes were 5 and 8 , respectively. Anaesthesia was continued with fentanyl $\left(7 \mu \mathrm{g} \cdot \mathrm{kg}^{-1}\right)$ and $\mathrm{N}_{2} \mathrm{O}$ in oxygen $(60 / 40)$. The patient awoke from anaesthesia and the tra-
TABLE Patient's data

\begin{tabular}{lcccc}
\hline & Baseline & Induction & Intubation & Extubation \\
\hline BP mmHg & $120 / 70$ & $90 / 50$ & $125 / 75$ & $110 / 70$ \\
HR bpm & 75 & 70 & 78 & 65 \\
FHR bpm & 150 & 143 & 146 & - \\
CVP mmHg & 5 & 4 & 5 & 7 \\
$\mathrm{SpO}_{2} \%$ & 96 & 100 & 98 & 97 \\
$\mathrm{PETCO}_{2} \mathrm{mmHg}$ & - & 31 & 33 & - \\
\hline
\end{tabular}

$\mathrm{BP}=$ blood pressure; $\mathrm{HR}$ = heart rate; FHR = foetal heart rate; $\mathrm{CVP}=$ central venous pressure; $\mathrm{SpO}_{2}=$ oxygen saturation; $\mathrm{PETCO}_{2}=$ end-tidal $\mathrm{CO}_{2}$.

chea was extubated after clinical recovery from neuromuscular block. The BP was $110 / 70 \mathrm{mmHg}$ and heart rate was $65 \mathrm{bpm}$ and she had no pain. Postoperative pain was managed in ICU by continuous infusion of morphine sulphate $\left(15 \mathrm{mg} \cdot \mathrm{day}^{-1}\right)$ and ketorolac $(90$ $\mathrm{mg} \cdot$ day $^{-1}$ ). The BP, ECG and CVP were continuously monitored for three days and transthoracic echocardiography was performed daily. The patient, continuing antihypertensive and anticoagulant therapy, was discharged from hospital in stable clinical condition on postoperative day 10 . She refused reoperation for aortic dissection

\section{Discussion}

The cardiovascular changes during pregnancy are particularly dangerous in patients with Marfan syndrome because of the increased pulsatile shear stress on the aortic wall. ${ }^{3}$ Under the combined influence of oestrogens and renin, both left ventricular end-diastolic volume $^{4}$ and wall tickness ${ }^{5}$ increase and there is progressive deterioration of the elastic tissue of the aorta. New onset or worsening of previous aortic incompetence may occur, particularly if uncontrolled hypertension is present. Prophylactic cardiac surgery is usually recommended when the ascending aorta exceeds $50 \mathrm{~mm} .^{6}$ However, surgery must be anticipated in case of rapid aortic expansion or when the aortic wall is very thin. During pregnancy, the clinical decision to operate on these patients is very challenging. Associated medical management is based on antihypertensive drugs which decrease shear stress and reduce aortic dilation. ${ }^{7}$ Betasympathetic blocking drugs are most effective drugs in reducing aortic shear stress in Marfan patients.

General anaesthesia was chosen instead of epidural anaesthesia because the patient was anticoagulated and treated with $\alpha$ - and $\beta$-blockers, which may cause marked hypotension when associated with the administration of local anaesthetics. ${ }^{8}$ The goal of anaesthetic management was to avoid or reduce the use of central nervous system and cardiopulmonary depressant drug 
administration before foetal delivery, and to ensure a stable haemodynamic environment for the mother.

All drugs used were considered to be safe for a normal mother and foetus. ${ }^{4}$ Propranolol and lidocaine were given before tracheal intubation to prevent an undesirable increase in BP and/or HR at induction, which may occur during laryngoscopy or after thiopentone administration. Labetalol $\left(1 \mu \mathrm{g} \cdot \mathrm{kg}^{-1} \cdot \mathrm{min}^{-1}\right)$, titrated to allow rapid control of $\mathrm{BP}$, is safe during delivery. ${ }^{4} \mathrm{We}$ chose labetalol instead of other antihypertensive agents because the combination $\alpha$ of $\beta$ and blockade may be preferable to the use of only $\beta$-blockers or vasodilators. The site of surgical incision was infiltrated with topical anaesthetic to reduce the need for intravenous anaesthesia and to attenuate postoperative pain. ${ }^{9}$ Topical anaesthesia may also reduce the hyperdynamic response to surgical manoeuvres during light anaesthesia prior to delivery and may attenuate the aortic shear stress. Intraoperative transoesophageal echocardiography allowed continuous monitoring of left ventricular function and may be used to detect aortic rupture. ${ }^{10}$

\section{Conclusion}

Caesarean section in an anticoagulated Marfan patient with recurrent aortic dissection was performed by minimizing the haemodynamic stress to the aorta. Intraoperative imaging of the thoracic aorta was used to early detect aortic rupture and/or extension of the dissecting haematoma. Finally, the delivery was performed in a cardiac surgery theatre to enable treatment of potentially life-threatening complications.

\section{References}

1 Pratt Rossiter J, Repke JT, Morales AJ, Murphy EA, Pyeritz RE. A prospective longitudinal evaluation of pregnancy in the Marfan syndrome. Am J Obstet Gynecol 1995; 173: 1599-606.

2 Pyeritz RE, McKusick VA. The Marfan syndrome: diagnosis and management. N Engl J Med 1979; 300: 772-7.

3 Williams GM, Gott VL, Brawley RK, Schauble JF, Labs JD. Aortic disease associated with pregnancy. J Vasc Surg 1988; 8: 470-5.

4 Mangano DT. Anesthesia for the pregnant cardiac patient. In: Shnider SM, Levinson G (Eds.). Anesthesia for Obstetrics, 2nd ed. Baltimore: Williams and Wilkins, 1987: 345-81.

5 Katz $R$, Karliner JS, Resnik $R$. Effects of a natural volume overload state (pregnancy) on left ventricular performance in normal human subjects. Circulation 1978; 58: 434-41.

6 Crawford ES, Hess KR, Cohen ES, Coselli JS, Safi HJ. Ruptured aneurysm of the descending thoracic and thoracoabdominal aorta. Analysis acccording to size and treatment. Ann Surg 1991; 213: 417-25.
7 Finkbohner R, Johnston D, Crawford ES, Coselli J, Milewicz DM. Marfan syndrome. Long-term survival and complications after aortic aneurysm repair. Circulation 1995; 91: 728-33.

8 Jayaram A, Carp HM, Davis L, Jacobson S-L. Pregnancy complicated by aortic dissection: Caesarean delivery during extradural anaesthesia. $\mathrm{Br} \mathrm{J}$ Anaesth 1995, 75: 358-60.

$9 \mathrm{Dahl} J \mathrm{~B}$, Kehlet $H$. The value of pre-emptive analgesia in the treatment of postoperative pain. $\mathrm{Br} J$ Anaesth 1993; 70: 434-9.

10 Practice guidelines for perioperative transesophageal echocardiography. A report by the American Society of Anesthesiologists and the Society of Cardiovascular Anesthesiologists Task Force on transesophageal echocardiography. Anesthesiology, 1996; 84: 986-1006. 